\title{
Richard Payne. "Territorializing Iran in Late Antiquity: Autocracy, Aristocracy, and the Infrastructure of Empire"
}

\section{Alessia Zubani}

\section{(2) OpenEdition Journals}

Édition électronique

URL : http://journals.openedition.org/abstractairanica/47990

DOI : 10.4000/abstractairanica.47990

ISBN : 1961-960X

ISSN : 1961-960X

Éditeur :

CNRS (UMR 7528 Mondes iraniens et indiens), Éditions de l'IFRI

\section{Référence électronique}

Alessia Zubani, « Richard Payne. "Territorializing Iran in Late Antiquity: Autocracy, Aristocracy, and the Infrastructure of Empire" », Abstracta Iranica [En ligne], Volume 40-41 | 2019, document 4, mis en ligne le 15 juillet 2019, consulté le 17 avril 2021. URL : http://journals.openedition.org/abstractairanica/ 47990 ; DOI : https://doi.org/10.4000/abstractairanica.47990

Ce document a été généré automatiquement le 17 avril 2021.

Tous droits réservés 


\title{
Richard Payne. "Territorializing Iran in Late Antiquity: Autocracy, Aristocracy, and the Infrastructure of Empire"
}

\author{
Alessia Zubani
}

\section{RÉFÉRENCE}

Richard Payne. "Territorializing Iran in Late Antiquity: Autocracy, Aristocracy, and the Infrastructure of Empire" in Clifford Ando, Seth Richardson (eds.). Ancient states and Infrastructural Power. Europe, Asia, and America. Philadelphia: University of Pennsylvania Press, 2017, p. 179-217

1 La cour sassanide se devait d'être la gardienne de l'Ērānšahr, en raison des efforts faits pour restaurer l'unité territoriale mythico-géographique reçue comme l'héritage des prestigieux ancêtres. La position privilégiée de l'espace dans la pensée politique sassanide et la relation existante entre les géographies réelle et imaginée expliquent les différentes politiques infrastructurelles par lesquelles la cour gouvernait l'empire. L'étude de la production et modification du territoire par l'autorité aide à comprendre la nature de la souveraineté des "Rois des rois ", souvent jugée à tort comme une forme de pouvoir despotique. En réalité il est possible de constater qu'elle dépendait plutôt du succès de son dialogue avec les pouvoirs aristocratiques qui obligeaient le roi à redéfinir sans cesse les termes de son autocratie. Le processus de territorialisation se renforçait pendant les siècles à travers la construction des sanctuaires et des villes échos de l'idéologie royale et instruments de contrôle et de l'exercice du pouvoir -, en s'intensifiant au Ve siècle. En faisant appel à l'exemple offert par les complexes de Gurgān et de l'Azerbaïdjan, l'A. montre aussi comment l'étude des transformations infrastructurelles peuvent aider à mieux comprendre les variations des dynamiques 
entre les élites aristocratiques et le pouvoir royale à l'époque sassanide tardive, toujours fluctuant entre formes de persuasion et de coercition.

\section{AUTEURS}

\section{ALESSIA ZUBANI}

Doctorante EPHE, Mondes iranien et indien, Paris 